\title{
The Impact of Mining on the Water Resources in Ghana: Newmont Case Study at Birim North District (New Abirem)
}

\author{
Francis Attiogbe ${ }^{1} \&$ Andrews Nkansah $^{1}$ \\ ${ }^{1}$ University of Energy and Natural Resources, Department of Energy and Environmental Engineering, Sunyani, \\ Ghana \\ Correspondence: Andrews Nkansah, Department of Energy and Environmental Engineering, University of Energy \\ and Natural Resources, Sunyani, Ghana. Tel: 4591-609-830. E-mail: ankansah@hotmail.com
}

Received: October 5, 2017

Accepted: October 15, 2017

Online Published: October 18, 2017

doi:10.5539/eer.v7n2p27

URL: https://doi.org/10.5539/eer.v7n2p27

The Research is financed by the authors and the University of Energy and Natural Resources.

\begin{abstract}
Mining activities accelerate the rate and degree of changes in the natural environment. These activities modify landscapes and can have long-term pollution impacts on communities and water resources due to their physical degrading nature, as well as their use of chemicals and other harmful substances. This study carried out by Department of Energy and Environmental Engineering of the University of Energy and Natural Resources therefore sought to assess the role of Newmont Akyem towards affecting the various water bodies in Akyem District. Qualitative and quantitative comparative methods were used for gathering data and performing analysis. The findings indicated that the physico-chemical parameters tested for the water bodies were all within the EPA, Ghana standards for drinking water except for the Pra River which recorded high levels of TSS indicating that there was, possibly, illegal mining activities upstream affecting the quality of the water. The study recommends that government provides both training and equipment to support small scale miners to avoid illegal mining. Also mining companies should contribute towards developing alternative livelihood for communities on whose lands they occupy. EPA should enforce environmental laws to protect the water bodies and the environment.
\end{abstract}

Keywords: Mining activities, environment, physico-chemical analysis, pollution, water resources 


\section{Introduction}

Mining is required to obtain any non-renewable resource that can't be grown or created artificially in a factory or laboratory (Iminco, 2017). Africa is well endowed with mineral resources. It harbours the world's largest mineral reserves of platinum, gold, diamonds, chromite, manganese, and vanadium. However, most of these minerals are exported as ores, concentrates or metals without significant downstream processing to add value. This has led to the persistent belief that the untapped mineral potential can act as a springboard for Africa's industrialization (UNEC, 2009). However, mining activities affect the rate of contamination of water resources due to their physical degrading nature, as well as use of chemicals and other harmful substances (Adjei, 2012). This implies that the quest to explore mineral resources, whether small- or large-scale, poses a threat to the water resources (surface and groundwater resources). And this fear is what initiated this study.

There is a very long history of mining in Ghana. In particular, there is evidence of gold mining and a gold trade with North Africa going back to the middle ages. Thus, Ghana's mining production is largely driven by gold, contributing more than 95 per cent of the country's total mineral revenue (Ghana Chamber of Mines, 2015). The other commercially exploited minerals in Ghana include manganese, bauxite and diamonds. Besides, the country is also endowed with many more under-exploited deposits of iron ore, limestone, columbite-tantalite, feldspar, quartz and salt (Ghana Chamber of Mines, 2006).

The mining sector plays an important role in the Ghanaian economy as it attracts more than half of all foreign direct investment (FDI), generates more than one-third of all export revenues, is the largest tax-paying sector in the country and makes a significant contribution to gross domestic product (GDP) as well as employment creation.

Mining in Ghana has been done both on large and small scales; both professionally and unprofessionally. Each of this has consequences on the precious water bodies.

The use of water in mining has the potential to affect the quality of surrounding surface water and groundwater which is often cited as a major concern among stakeholders. Mining operations, whether small or large scale, often involve the use of water which impacts water resources, even in the long term after the closure of the operations (Gardner et al., 2015).

In the past, mines in Ghana operated without the environmental management strategies and control technologies that are standard practice among larger mining companies today, contributing to environmental concerns over proposed mines. A study conducted by the Commission of Human Rights and Administrative Justice (CHRAJ) in 2007 revealed that many rivers and streams which hitherto, provided water for the mining communities have been destroyed, polluted or dried up. Illegal small-scale mining has been identified as a major factor militating against sound environmental practices in the mining industry through the discharge of mercury and other pollutants into streams and rivers. However, the 'reckless spillage of cyanide'by large mining companies also contributes enormously to the pollution of rivers and streams within these areas, thus posing threats to human existence and aquatic life (Nasirudeen, 2015).This study therefore sought to assess the role of Newmont Akyem towards promoting sustainable mining with zero or minimal impact on the water resources.

\section{Characteristics of the Study Area}

Geographically, the study is limited to the Birim North District and the communities within the district. The Birim North District was carved out of the former Birim District Council in 1987 as part of the Government's decentralisation programme to promote effective decentralised governance and speed up the development of the area. It is found in the Eastern region of Ghana. With improved road conditions linking the district to the commercial centres, the district has huge economic potential. The district covers an estimated total land area of 1,250 square kilometres, covering about 6.47 percent of the total land area of the Eastern Region (Birim North District, 2006).

New Abirem the study area, like many other gold bearing places in Ghana, is covered with the Paleoprotoerozoic rocks of the Birimian Super group and the overlying classic sedimentary Tarkwaian group. Asa result of a series of erosional events, however, significant portions of these rocks have been re-deposited as placer formations in a number of streams and channels. Placer Gold Deposits, which are also referred to as 'alluvial gold', are found in the majority of rivers draining Birimian rocks in Ghana. Large deposits of placer gold also occur along the terraces, floodplains, channels and river beds of the Offin, Pra, Ankobra, Birim and Tano rivers part of which drain the study area (Adjei et al., 2012). 


\section{STUDY AREA IN NATIONAL CONTEXT}

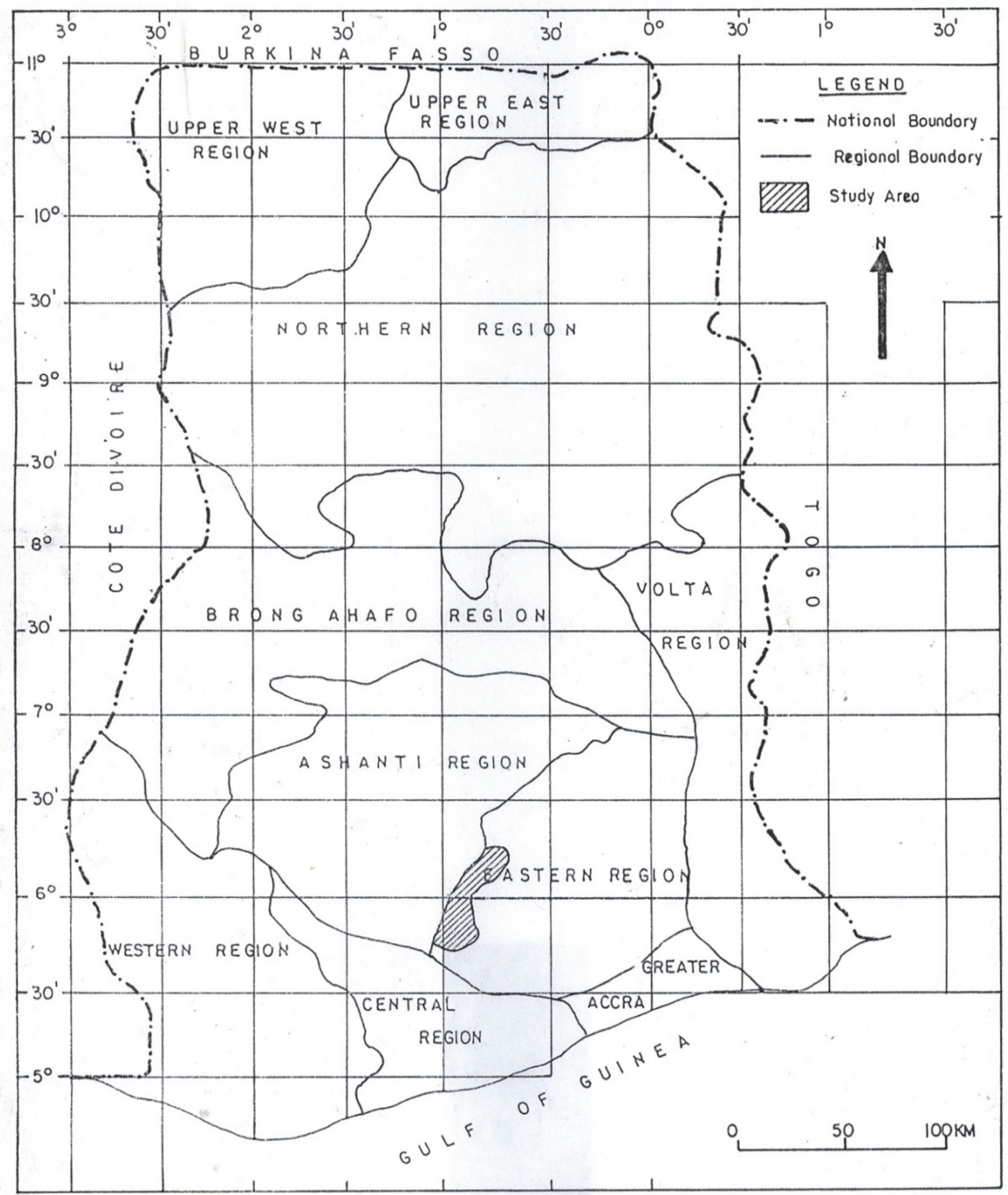

Figure 1. Map of Ghana showing study area (Kumasi Metropolitan Assembly, 2008)

The localities within which Newmont Ghana Gold Limited (NGGL) operates are also highlighted and illustrated in the Figure 2 below. 


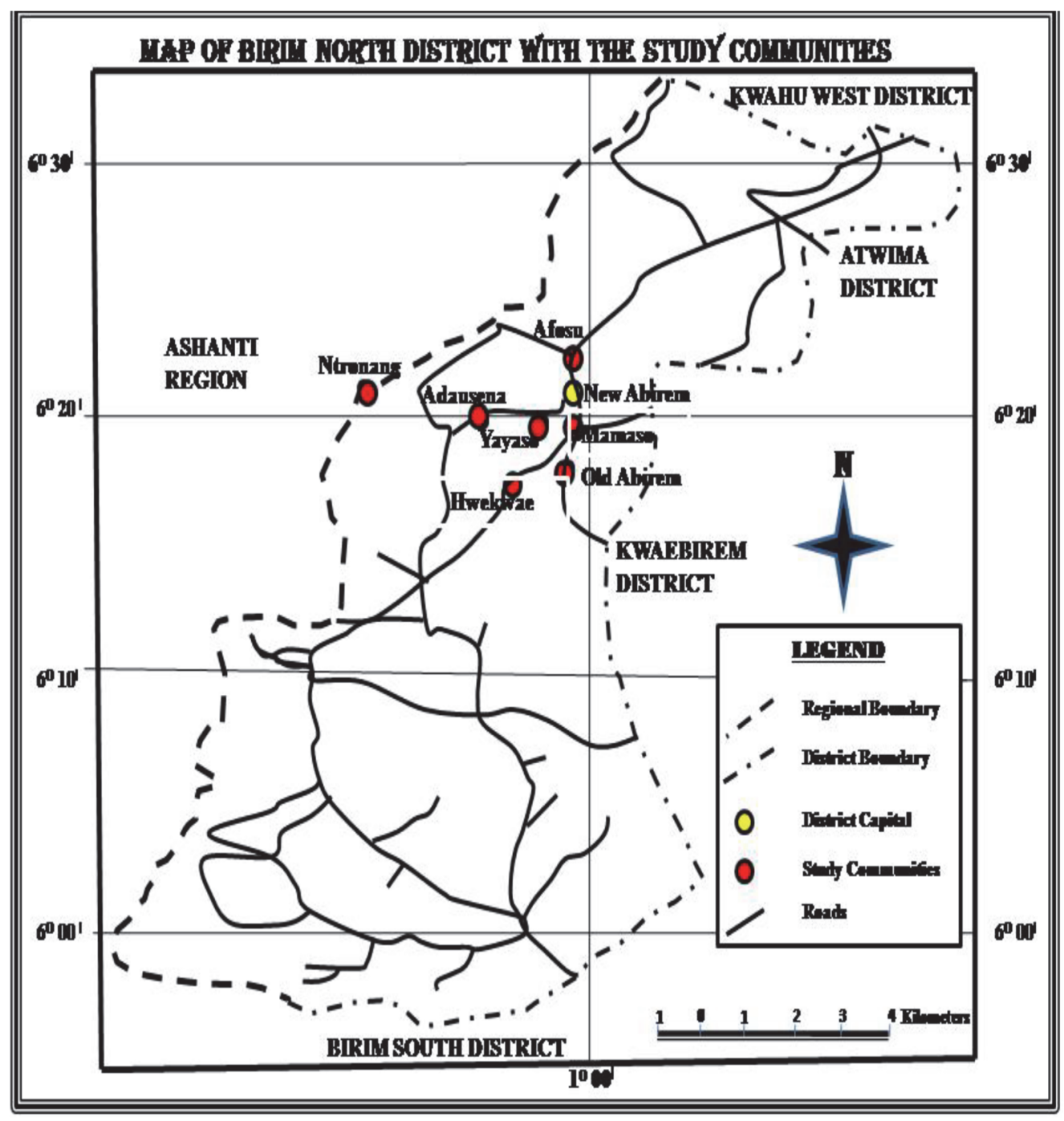

Figure 2. Context Map of Birim North District (Birim North District, 2006)

\subsection{The Operations of Newmont Golden Ridge Limited (Newmont Akyem) at the Study Area}

Newmont Akyem Project site is located in the Birim North District. The Project is located approximately 3 kilometres west of the district capital called New Abirem which is 133 kilometres west of Koforidua, the regional capital; and 180 kilometres northwest of Accra. The site development lies within an area belonging to the Kotoku Paramountcy. Newmont Akyem which mines gold as the major product, operates as a surface mining entity. It therefore has an open pit mine and a waste rock disposal facilities. Besides, it has a tailings storage facility, ore processing plant, water storage dam and reservoir, water transmission pipeline, sediment control structures and ditches, haul and access roads and supporting facilities such as medical unit, administration building, plant warehouse, explosives magazine, fire service facility, assay laboratory, and personnel accommodations (Birim North District, 2006).

\subsection{Conditions of the Natural Environment and Water Resources}

The Birim North district is one of the forested districts in the country. Parts of these forests have been reserved to ensure sustainable use of the natural resources resulting in the creation of nine forest reserves to preserve part of the original vegetation in the district. However, a number of factors have contributed immensely to the reduction of the forest cover in the district. Prominent among these are poor farming practices, lumbering (especially the activities of illegal chainsaw operators), bush fires and irresponsible mining activities. These human activities especially along the banks of the Pra River have resulted in its headwaters getting dry up every year during the dry season. This normally causes perennial water shortages in communities, which depend on it for their water supply. The situation can worsen if mining activities pollute these water resources (Birim North District, 2006). 


\subsection{Surface Water Resources}

The district is drained mainly by two great historical rivers: the Pra and its tributaries; and the Birim and its tributaries. However, the study area is located in the Pra River basin which flows south to the Gulf of Guinea in the Atlantic Ocean. The Pra River is the second largest river in Ghana with a total drainage area of 23,170 square kilometres. Streams and rivers in the study area generally flow during the raining season (May to November), with reduced or no flow occurring during the dry season (December to April). Lower reaches of the Pra River generally flow year-round (perennial) whereas the upper Pra River, all of the Mamang River and the other tributary streams flow seasonally during raining periods. During dry periods, portions of channels that become dry often contain shallow pools of water (Newmont, 2008; Birim North District, 2006).

\subsection{Groundwater Resources}

Three general rock units are considered potential aquifers (from top to bottom) in the study area: saprolite, sap rock and bedrock. Overall, groundwater recharge rate is estimated at about 70-140 millimetres per year, which is 5-10 percent of total annual precipitation (1,370millimeters). Groundwater discharge in the area occurs to wetland areas, springs and some streams and rivers (Newmont, 2008).

\section{The Study Hypothesis}

Newmont had conducted environmental impacts of their activities and had reported of no environmental pollution. This study therefore was set out to verify the claim as well as determine whether there has been deterioration of the condition after the Newmont study. Therefore the research methodology was designed to get the view and experiences of the mining communities as well as undertake laboratory assessment of possible contamination of the mining activities in the communities.

\section{Methodology}

Qualitative and quantitative methods were used for data gathering and analysis. For primary data, it was obtained through the participants' and non-participants' observation to allow informed and detailed information about the activities of Newmont towards sustainable mining and its effects on water quality, on the people and their communities as a whole.

Secondary data was sourced from EPA concerning water quality tests done by Newmont. These were then compared with results of the researchers for this study. Extensive review of related issues in the news, journals and publications was also done to augment and triangulate the study.

The data gathering tools were a phone recorder, a computer, pen and a note book. Interview guide was used in conducting the surveys. Through a screening technique, eligible respondents responded to close and open ended questions which were administered to them during the interview section. This instrument (the interview guide) enhanced and facilitated the data collection procedures.

\subsection{Data Source and Data Collection Procedure}

Respondents who had lived in the various affected communities over a longer period of time and some Newmont employees were targeted for the interview. Questions pertaining to the relevance of the studies were asked. With the use of a convenience sampling technique, 20 respondents were selected for the interview. The data collection process began on the $24^{\text {th }}$ January 2017 and ended on the $27^{\text {th }}$ of January 2017. Water samples were also collected and transported to the laboratory for analysis.

Secondary water sampling data done in the same area were collected from EPA, and compared with the researchers' findings to see if there were any differences of significance.

\subsection{Water Sampling}

\subsubsection{Sampling Sites}

Sampling points were carefully chosen in order to assess the water quality of the Afosu Stream, Pra and Mamang Rivers in Birim North District and its environs. The sampling points were both upstream and downstream.

\subsubsection{Method of Water Sampling}

Water samples for physico-chemical analysis were collected into $500 \mathrm{ml}$ plastic containers. Samples were stored in an ice chest containing ice and transported to the laboratory where some of the samples were filtered and preserved for trace metal analyses.

In sampling surface water, bottles labelled with the type of sample, location, site name, time and date were held near the base and its neck was plunged downward below the surface of the water body. Bottle was turned until the 
neck pointed slightly upwards, the mouth being directed towards the current of the water body. Bottles were filled directly from the water body. Colour, $\mathrm{pH}$, TDS, and TSS were measured on site.

\subsection{Data Processing and Analysis}

In the analysis, both qualitative and quantitative methods were used to measure the research objectives and process responses from the interviews conducted. The qualitative technique was in the form of comprehensive statements and analytical descriptions. A detailed descriptive narration and write up have been used for elaborations. Through a systematic recording and notes taking of narrations and experiences from direct and indirect beneficiaries, elaborations were done through qualitative analytical means. Through qualitative probing techniques, some issues surfaced prominently for discussion and analysis. In order to keep the main objectives in focus, the discussions and narrations, especially those of focus groups, were done with quite a level of control. This was done to triangulate the findings.

Quantitative method involved analysis of the water samples collected for the physico-chemical parameters most of which were tabulated or shown graphically.

\section{Results from the Laboratory}

\subsection{Physico-chemical Parameters of the Water Samples}

\section{Water Samples from Afosu Stream (SW 2A)}

Table 1 below presents results of the physico-chemical analysis of water samples collected from the Afosu Stream by this study as well as comparative study done by Newmont whose analysis results were by ACZ. The table contains both results from ACZ (independent) laboratory submitted to EPA of Ghana and results from samples collected by researchers of this study. The table indicates that, all the recorded values for the physico-chemical parameters were all within the EPA of Ghana guideline value.

Table 1. Physico-chemical parameters of water samples from the Afosu Stream

\begin{tabular}{llllll}
\hline Parameters & Mean $^{\mathbf{1}}$ & SD $^{\mathbf{1}}$ & Mean $^{\mathbf{2}}$ & SD $^{\mathbf{2}}$ & EPA Standard \\
\hline $\mathrm{pH}$ & 7.225 & 0.407 & 7.133 & 0.208 & $6-9$ \\
Colour (TCU) & 5.583 & 2.021 & 5.000 & 0 & 15 \\
TDS (mg/l) & 165.666 & 15.651 & 73.333 & 11.547 & 1000 \\
TSS (mg/l) & 18.750 & 11.354 & 9.000 & 3.605 & 50 \\
\hline
\end{tabular}

Mean $^{1}$ - results from ACZ (independent) laboratory located in Colorado submitted to EPA.

$\mathrm{SD}^{1}$ - standard deviation of results from ACZ (independent) laboratory located in Colorado, USA submitted to EPA.

Mean ${ }^{2}$ - results from samples collected by researchers of this project.

$\mathrm{SD}^{2}$ - standard deviation of results from samples collected by researchers of this project.

The mean values recorded for colour was 5.583(TCU) and 5(TCU) respectively which were all within the minimum standard requirement of EPA. Generally, there was a slightly negligible difference in the mean value from the ACZ laboratory results as compared to the samples taken by the researchers. The slight difference in $\mathrm{pH}$ might be due to the difference in the time both samples were taken and analysed. During the period of the study, the activities of illegal mining had increased in the study area, and this might have contributed to the difference in the results.

\section{Water Samples from Pra River (SW 22)}

The Pra River is the main source of abstraction for Newmont Akyem Mine. Results of the physico-chemical analysis of water samples from the Pra River are presented in table 2 below. From the table, all the recorded values for the physico-chemical parameters were all within the EPA guideline value except for TSS which recorded higher values. Since the main mining method here is surface mining a lot of earth materials are scooped out which eventually get into the river to increase the TSS. With time the heavy metals' concentration could also increase due to mineralization process. 
Table 2. Physico-chemical parameters of water samples from the Pra River

\begin{tabular}{llllll}
\hline Parameters & Mean $^{1}$ & SD $^{\mathbf{1}}$ & Mean $^{\mathbf{2}}$ & SD $^{\mathbf{2}}$ & EPA Standard \\
\hline $\mathrm{pH}$ & 7.336 & 0.320 & 7.530 & 0.115 & $6-9$ \\
Colour (TCU) & 8.909 & 4.721 & 10.333 & 9.192 & 15 \\
TDS (mg/l) & 172.181 & 57.968 & 156.667 & 7.071 & 1000 \\
TSS (mg/l) & 125.000 & 80.757 & 223.333 & 21.213 & 50 \\
\hline
\end{tabular}

Mean ${ }^{1}$ - results from ACZ (independent) laboratory located in Colorado submitted to EPA.

$\mathrm{SD}^{1}$ - standard deviation of results from ACZ (independent) laboratory located in Colorado, USA submitted to EPA.

$\mathrm{Mean}^{2}$ - results from samples collected by researchers of this project.

$\mathrm{SD}^{2}$ - standard deviation of results from samples collected by researchers of this project.

From the table, recorded colour values for the Pra River increased from 8.909(TCU) to 10.333(TCU). The difference is as a results of the time both samples were taken and analysed and also the increasing activity of illegal mining along the river banks at the time of this study. Nevertheless, all the other values were within the EPA maximum allowable limit.

High concentrations of TSS recorded would increase turbidity which would increase the surface area of solids in suspension upon which bacteria can grow. It also interferes with the disinfection rate. Also in situations where people drink directly from this river, it makes the water source aesthetically unpleasant.

\section{Water Samples from Mamang River (SW 28)}

Results of the physico-chemical analysis of water samples from the Mamang River are presented in Table 3 below. The recorded values for all the physico-chemical parameters were all within the EPA guideline value.

Table 3. Physico-chemical parameters of water samples from the Mamang River

\begin{tabular}{llllll}
\hline Parameters & Mean $^{\mathbf{1}}$ & SD $^{\mathbf{1}}$ & Mean $^{\mathbf{2}}$ & SD $^{\mathbf{2}}$ & EPA Standard \\
\hline $\mathrm{pH}$ & 7.181 & 0.577 & 7.166 & 0.212 & $6-9$ \\
Colour (TCU) & 5 & 0 & 5 & 0 & 15 \\
TDS (mg/l) & 116.909 & 13.575 & 120 & 7.071 & 1000 \\
TSS (mg/l) & 17.545 & 6.638 & 23.666 & 7.070 & 50 \\
\hline
\end{tabular}

Mean ${ }^{1}$ - results from ACZ (independent) laboratory located in Colorado submitted to EPA.

$\mathrm{SD}^{1}$ - standard deviation of results from ACZ (independent) laboratory located in Colorado, USA submitted to EPA.

$\mathrm{Mean}^{2}$ - results from samples collected by researchers of this project.

$\mathrm{SD}^{2}$ - standard deviation of results from samples collected by researchers of this project.

\subsection{Metal Analysis}

\section{Levels of Heavy Metals in Water Samples from the Afosu Stream (SW 2A).}

The mean values recorded for arsenic dissolved was 1.391(ppb-ug/l). This value is far below the EPA maximum allowable limit of $28(\mathrm{ppb}-\mathrm{ug} / \mathrm{l})$ for drinking water.

Cadmium dissolved and mercury dissolved were not analysed by the researchers. However, ACZ results for cadmium and mercury were below the EPA allowable limits.

Cyanide free, copper and arsenic dissolved, recorded mean values which were all by far below the EPA maximum allowable limit as seen in Table 4 below.

Table 4. Trace metal levels in water samples from the Afosu Stream

\begin{tabular}{llllll}
\hline Parameters & Mean $^{\mathbf{1}}$ & SD $^{\mathbf{1}}$ & Mean $^{\mathbf{2}}$ & SD $^{\mathbf{2}}$ & $\begin{array}{l}\text { EPA } \\
\text { Standard }\end{array}$ \\
\hline Arsenic Dissolved (ppb-ug/l) & 1.392 & 0.514 & 0 & 0 & 28 \\
Cadmium Dissolved (mg/l) & 0.0001 & $2.83 \mathrm{E}-20$ & - & - & 0.005 \\
Cyanide Free (ppb-ug/l) & 3.000 & 0 & 0 & 0 & 5 \\
\hline
\end{tabular}




\begin{tabular}{llllll}
\hline Copper Dissolved (mg/l) & 0.005 & 0.005 & 0 & 0 & 0.2 \\
Mercury Dissolved (mg/l) & 0.0002 & $5.66 \mathrm{E}-20$ & - & - & 0.001 \\
\hline
\end{tabular}

Mean ${ }^{1}$ - results from ACZ (independent) laboratory located in Colorado submitted to EPA.

$\mathrm{SD}^{1}$ - standard deviation of results from ACZ (independent) laboratory located in Colorado, USA submitted to EPA.

$\mathrm{Mean}^{2}$ - results from samples collected by researchers of this project.

$\mathrm{SD}^{2}$ - standard deviation of results from samples collected by researchers of this project.

\section{Levels of Heavy Metals in Water Samples from the Pra River (SW 22)}

Concentrations of $\mathrm{Ar}, \mathrm{Cd}, \mathrm{CN}, \mathrm{Cu}$ and $\mathrm{Hg}$, in water samples from the Pra River are presented in Table 5 below.

Table 5. Trace metal levels in water samples from the Pra River

\begin{tabular}{llllll}
\hline Parameters & Mean $^{\mathbf{1}}$ & SD $^{1}$ & Mean $^{2}$ & SD $^{\mathbf{2}}$ & EPA Standard \\
\hline Arsenic Dissolved (ppb-ug/l) & 1.200 & 0.219 & 0.001 & 0.001 & 28 \\
Cadmium Dissolved (mg/l) & 0.0001 & $2.84 \mathrm{E}-20$ & - & - & 0.005 \\
Cyanide Free (ppb-ug/l) & 3 & 0 & 0.001 & 0.001 & 5 \\
Copper Dissolved (mg/l) & 0.006 & 0.004 & 0 & 0 & 0.2 \\
Mercury Dissolved (mg/l) & 0.0002 & $5.69 \mathrm{E}-20$ & - & - & 0.001 \\
\hline
\end{tabular}

Mean $^{1}$ - results from ACZ (independent) laboratory located in Colorado submitted to EPA.

$\mathrm{SD}^{1}$ - standard deviation of results from ACZ (independent) laboratory located in Colorado, USA submitted to EPA.

$\mathrm{Mean}^{2}$ - results from samples collected by researchers of this project.

$\mathrm{SD}^{2}$ - standard deviation of results from samples collected by researchers of this project.

The mean concentrations of arsenic dissolved, cyanide free and copper dissolved recorded values which were all within the EPA guidelines limit. Similarly analysis of ACZ for cadmium and mercury were within the acceptable limits of EPA.

\section{Levels of Heavy Metals in Water samples from the Mamang River (SW 28).}

The results of researchers for this study as well as the one done by Newmont and analysed for them by ACZ showed mean concentrations of arsenic dissolved, cadmium dissolved, cyanide free, copper dissolved and mercury dissolved recorded all below and within the EPA guidelines limit (See Table 6 below).

Table 6. Trace metal levels in water samples from Mamang River

\begin{tabular}{llllll}
\hline Parameters & Mean $^{\mathbf{1}}$ & SD $^{\mathbf{1}}$ & Mean $^{\mathbf{2}}$ & SD $^{\mathbf{2}}$ & EPA Standard \\
\hline Arsenic Dissolved (ppb-ug/l) & 1.563 & 0.307 & 0.001 & 0.001 & 28 \\
Cadmium Dissolved (mg/l) & 0.0001 & $2.84 \mathrm{E}-20$ & - & - & 0.005 \\
Cyanide Free (ppb-ug/l) & 3.090 & 0.301 & 0.001 & 0.001 & 5 \\
Copper Dissolved (mg/l) & 0.005 & 0.004 & 0 & 0 & 0.2 \\
Mercury Dissolved (mg/l) & 0.0002 & $5.69 \mathrm{E}-20$ & - & - & 0.001 \\
\hline
\end{tabular}

$\mathrm{Mean}^{1}$ - results from ACZ (independent) laboratory located in Colorado submitted to EPA.

$\mathrm{SD}^{1}$ - standard deviation of results from ACZ (independent) laboratory located in Colorado, USA submitted to EPA.

$\mathrm{Mean}^{2}$ - results from samples collected by researchers of this project.

$\mathrm{SD}^{2}$ - standard deviation of results from samples collected by researchers of this project.

\section{Results from the Interview}

\subsection{Knowledge about Sustainable Mining and Its Adaptability}

Mining is an important activity which has the potential of contributing to the development of areas endowed with the natural resources. Many respondents confirmed this by stating that mining can be made sustainable if the right 
measures are put in place by the mining companies. Many of the key informants advised that stakeholders and authorities of the environment should ensure that other mining companies adapt to sustainable mining as the one practised by Newmont Akyem. Almost all the interviewees were happy about the mining activities of the Newmont Akyem. However, many were against the practices of the galamsey (illegal mining) as their activities visibly destroyed the environment and polluted the water bodies. Nevertheless, they were sympathetic towards the illegal miners' livelihoods which were based on mining, and therefore advised that government find alternative livelihood for them to stop their illegal activities or assist them to mine responsibly through training and necessary mining equipment.

\section{Discussion}

\subsection{Physico-Chemical Quality of the Afosu Stream, Pra and Mamang Rivers}

Generally the values recorded for the physico-chemical parameters from the Afosu Stream and the Mamang River were all within the EPA guideline requirement. Comparing both results from the ACZ laboratory and the researchers', Pra River recorded increase in TSS which indicates possible anthropogenic influence such as illegal mining (popularly known in Ghana as galamsey) upstream of River Pra. There was also slight reduction in $\mathrm{pH}$. This was evident in both the EPA (from ACZ) and the researchers' data results. Galamsey involves activities that loosen the soil or disturb the soil structure, and, hence could facilitate the leaching of certain ions into water bodies to influence the $\mathrm{pH}$.

Comparing the results from both ACZ laboratory and the researchers', it was realised that almost all the mean results from the analysis were all within the EPA maximum allowable limit. Thus considering the physico-chemical results, it could be inferred that the activities of Newmont Akyem doesn't affect the quality of the water bodies badly.

\subsection{Metal Concentrations}

The results of the heavy metal analysis of water samples from the Afosu Stream, Pra and Mamang Rivers showed that, cyanide, arsenic, mercury, cadmium and copper were present in dissolved form in measurable quantities for the EPA data results. Comparing the results of both ACZ laboratory and the researchers, it was realised that the differences in values were minimal and also all the values were within the EPA maximum allowable limit. Generally, copper, arsenic, cyanide, cadmium and mercury concentrations measured in the water samples were lower than the respective EPA acceptable limits of drinking water from the independent data results. This also emphasizes the fact that Newmont Akyem mining practices have not significantly endangered the qualities of the water bodies.

\section{Conclusions}

The results of this study assessing sustainable mining practices at Newmont Akyem and its impacts on water quality after four years of mineral extraction have generally shown low levels of some of the examined heavy metals and the physico-chemical parameters of the rivers and stream in the operation area of the mine during the period of sampling.

The following conclusions were made based on the results obtained after this research in accordance with the objective:

Mean values for, $\mathrm{pH}$, colour, TDS and TSS recorded were within the EPA recommended guideline values for drinking water. Except for the Pra River which recorded high value of TSS indicating possible activities of galamsey upstream.

Comparing the results of both ACZ laboratory (by Newmont) and the researchers (of this study), it was realised that the differences in values were slightly negligible and also all the mean values recorded were all within the EPA maximum allowable limit due to the practice of zero discharge by the Newmont Akyem Mine. All the wastewater from gold processing that ends up in the tailings storage facility is recycled back into the process plant and reused. All mine water is recycled hence preserving quantity and quality. This implies that the pollution impact of gold mining activities by Newmont Akyem on the water bodies in the study area is very minimal giving some element of credence that, their mining activity has so far been sustainable. Generally interviewees were happy with the activities of the Newmont Akyem's mining activities as, in their view, the company adopts the right environmental measures to minimize pollution. However, they were concerned about the activities of the illegal miners as their work pollutes and destroys the environment.

\section{Recommendations}

Ghana's highest potential for short to medium-term growth and development lies on mineral resource endowment, 
therefore more needs to be done in relation to sustainable mining practices. It is thus recommended that, there is the need for broader structuring of mining contracts by stakeholders to ensure that miners have the right requisites for their job. Also the local residents in the mining areas should benefit substantially from mineral revenues to enable them to fight poverty and prevent them from irresponsible mining which destroys the environment. This means that there should be public campaigns to educate against illegal small scale mining that destroys the environment. g. Alternative livelihood could be instituted for those engaged in the illegal small scale mining activities. Where communities' farmlands have been encroached by mining activities, mining companies could pay higher percentage as royalties and provide business opportunities in place of farming

Mining companies should give great weight to water management and treatment so as to improve both water quality and quantity as well as protect aquatic ecosystems in the communities in which they operate. EPA should also strictly enforce primary jurisdiction over mining operations within the borders of Ghana and control water pollution from mines on a case-by-case basis through permit and license conditions.

\section{Acknowledgements}

This study was made possible through the help and support from its contributors, family and friends. First and foremost, I would like to thank Dr. Francis Attiogbe for his leading role and financial contribution towards the publication of this paper. Second, I would like to thank all the students of the Department of Energy and Environmental Engineering of the University of Energy and Natural resources for the field data collection and analysis. Finally, I sincerely thank the authorities of the University of Energy and Natural Resources, Sunyani, for their moral and financial encouragement to publish quality papers.

\section{References}

Adjei, S. N. I. A. (2012). The Impact and Effect of Illegal Mining (galamsey) towards the Socio-economic Development of Mining Communities: International Journal of Modern SocialSciences, p. 43.

Adjei, S., Oladejo, N. K., \& Adetunde, I. A. (2012). The Impact and Effect of Illegal Mining (galamsey) towards the Socio-economic Development of Mining Communities:. International Journal of Modern SocialSciences, 43-45.

Birim North District. ( 2006). District Medium Term Development Plan.

CHRAJ. (2008). Study on the State of Human Rights in Mining Communities in Ghana. Retrieved from http://www.nodirtygold.org/

Gardner, A., Duff, N., Ainuson, K., \& Manteaw, S. (2015). Regulating Mining Water Use and Impacts in Ghana:Comparing Australian and Ghanaian Law for Reform Ideas, Australia: s.n.

Ghana Chamber of Mines. (2006). Draft Minerals and Mining Policy of Ghana.

Ghana Chamber of Mines. (2015). Mining in Ghana- What future can we expect?

Human Rights in Ghana Mining Communities. pdf [Accessed: August 18, 2017].

Iminco. (2017). Retrieved from http://iminco.net/what-is-mining

Nasirudeen, A. F. ( 2015). Mikashini's Blog.

Newmont. (2008). Environmental Impact Statement Akyem Gold Project. Akyem: Newmont.

UNECA. (2009). Africa Review Report on Mining, Addis Ababa, Ethiopia: United Nations Economic and Social Council.

\section{Copyrights}

Copyright for this article is retained by the author(s), with first publication rights granted to the journal.

This is an open-access article distributed under the terms and conditions of the Creative Commons Attribution license (http://creativecommons.org/licenses/by/4.0/). 